\title{
Life Cycle Assessment of Advanced Circulating Fluidized Bed Municipal Solid Waste Incineration System from an Environmental and Exergetic Perspective
}

\author{
Jun Li ${ }^{1}$, Lixian Wang ${ }^{1}$, Yong Chi ${ }^{1, *}$, Zhaozhi Zhou ${ }^{2}$, Yuanjun Tang ${ }^{3}$ and Hui Zhang ${ }^{1}$ \\ 1 State Key Laboratory of Clean Energy Utilization, Zhejiang University, Hangzhou 310027, China; \\ 21860062@zju.edu.cn (J.L.); wanglixian@zju.edu.cn (L.W.); zhanghui626@zju.edu.cn (H.Z.) \\ 2 Zhejiang Development \& Planning Institute, Hangzhou 310012, China; 11527033@zju.edu.cn \\ 3 Department of Energy and Environment System Engineering, Zhejiang University of Science and Technology, \\ Hangzhou 310023, China; tang@zust.edu.cn \\ * Correspondence: chiyong@zju.edu.cn
}

\section{check for} updates

Citation: Li, J.; Wang, L.; Chi, Y.; Zhou, Z.; Tang, Y.; Zhang, H. Life Cycle Assessment of Advanced Circulating Fluidized Bed Municipal Solid Waste Incineration System from an Environmental and Exergetic Perspective. Int. J. Environ. Res. Public Health 2021, 18, 10432. https:// doi.org/10.3390/ijerph181910432

Academic Editors: Yu-Pin Lin and Marta Otero

Received: 24 July 2021

Accepted: 30 September 2021

Published: 3 October 2021

Publisher's Note: MDPI stays neutral with regard to jurisdictional claims in published maps and institutional affiliations.

Copyright: (c) 2021 by the authors. Licensee MDPI, Basel, Switzerland. This article is an open access article distributed under the terms and conditions of the Creative Commons Attribution (CC BY) license (https:/ / creativecommons.org/licenses/by/ $4.0 /)$.

\begin{abstract}
The production of clean and efficient energy from municipal solid waste (MSW) is extremely urgent matter due to an increasing energy demand and environmental concerns. In this study, a high steam parameter $\left(520^{\circ} \mathrm{C}, 7.9 \mathrm{MPa}\right)$ circulating fluidized bed (CFB) MSW incineration system, equipped with a mechanical, biological treatment and external heat exchanger systems, was introduced and a comparative study with a typical mechanical grate $\left(450{ }^{\circ} \mathrm{C}, 5.3 \mathrm{MPa}\right)$ incineration system and conventional CFB $\left(485^{\circ} \mathrm{C}, 5.3 \mathrm{MPa}\right)$ incineration system was carried out from a life-cycle, environmental and exergetic perspective which could assess different energy and material outputs based on real operating data. Moreover, the potential system optimization of this advanced CFB system was proposed. The results showed that the advanced CFB system was more environmentally friendly and resource-efficient than conventional MSW incineration systems. The recovery of material should be given priority over energy recovery. According to the assessment of the environment, and energy and material recovery, a process improvement with an incinerated refuse-derived fuel and a semi-compost produced by MBT as a soil conditioner was highly recommended.
\end{abstract}

Keywords: environmental life cycle assessment; exergetic life cycle assessment; municipal solid waste; mechanical biological treatment; environmental burdens; resource use efficiencies

\section{Introduction}

The generation of municipal solid waste (MSW) has increased dramatically with the vast growth of population and urbanization in recent years in China. According to the official reports [1], in China there were 158.05 and 215.21 million tons of MSW produced in 2010 and 2017, respectively, corresponding to an annual increase rate of $4.5 \%$. Meanwhile, the relevant harmless treatments for MSW were also developed, especially the MSW incineration technology due to its advantages for significant waste mass and volume reduction, complete disinfection, and energy recovery [2]. However, the electricity recovery efficiency of the MSW incineration plant is usually as low as approximately $20 \%$. The reasons for this are mainly attributed to not only the low-grade fuels, but also to the low steam parameters due to the high-temperature $\mathrm{HCl}$ corrosive effect [3]. The chlorinecontaining MSW brings chlorine to flue gas which leads to the emergence of $\mathrm{HCl}$ [4]. At a temperature above $450{ }^{\circ} \mathrm{C}$, acid flue gas containing $\mathrm{SO}_{2}$ and $\mathrm{HCl}$ can corrode the heat transfer surface [5].

To obtain a higher energy recovery from MSW, an advanced circulating fluidized bed (CFB) incineration system equipped with a mechanical biological treatment (MBT) system and final steam superheater used as external heat exchanger (EHE) located in solids return, was investigated and constructed to achieve high steam parameters in 
order to make the MSW incineration system more environmentally friendly and energy efficient, while its environmental savings, resource benefits, and energy efficiencies lacked a quantitative evaluation.

For part of the MBT system, the integrated material recovery and valorization system improve resource efficiency. The poly-generation of the MBT system enhances product diversification and minimizes financial risks [6]. MBT has an optimal net environmental impact for MSW treatment [7]. In short, due to material recovery and fuel upgrading, the MBT system is considered a promising method for MSW treatment [8]. A more detailed description concerning the equipment is clarified in the Supplementary Materials.

For the part of the EHE system, an external heat exchanger (EHE) located in the solids returns is widely used in large CFB systems, as shown in Figure 1 [9]. The EHE is beneficial for making the boiler load adaptable and for regulating the bed temperature [10]. The EHE is convenient and flexible for the design of heating surfaces, owing to its adjustable solid flow rate and good heat transfer characteristics [11]. The EHE works as a high temperature heat transfer that exchanges heat between the flowing steam inside the transfer and solid particles instead of flue gas. Therefore, it helps obtain a high steam parameter and high electricity recovery, especially in MSW incineration plants without the issue of the hightemperature $\mathrm{HCl}$ corrosive effect which strictly limits the main steam parameters (usually below $450{ }^{\circ} \mathrm{C}, 4.0 \mathrm{MPa}$ ). However, in our study, with the use of EHE, the main steam parameters can reach up to $520^{\circ} \mathrm{C}$ and $7.9 \mathrm{MPa}$ and help achieve energy recovery efficiency as high as $28 \%$. The EHE system uses high-temperature ash and waste particles as a heat resource where there is no participation of corrosive flue gas. This is why this system does not present the problem of the $\mathrm{HCl}$ corrosive effect.
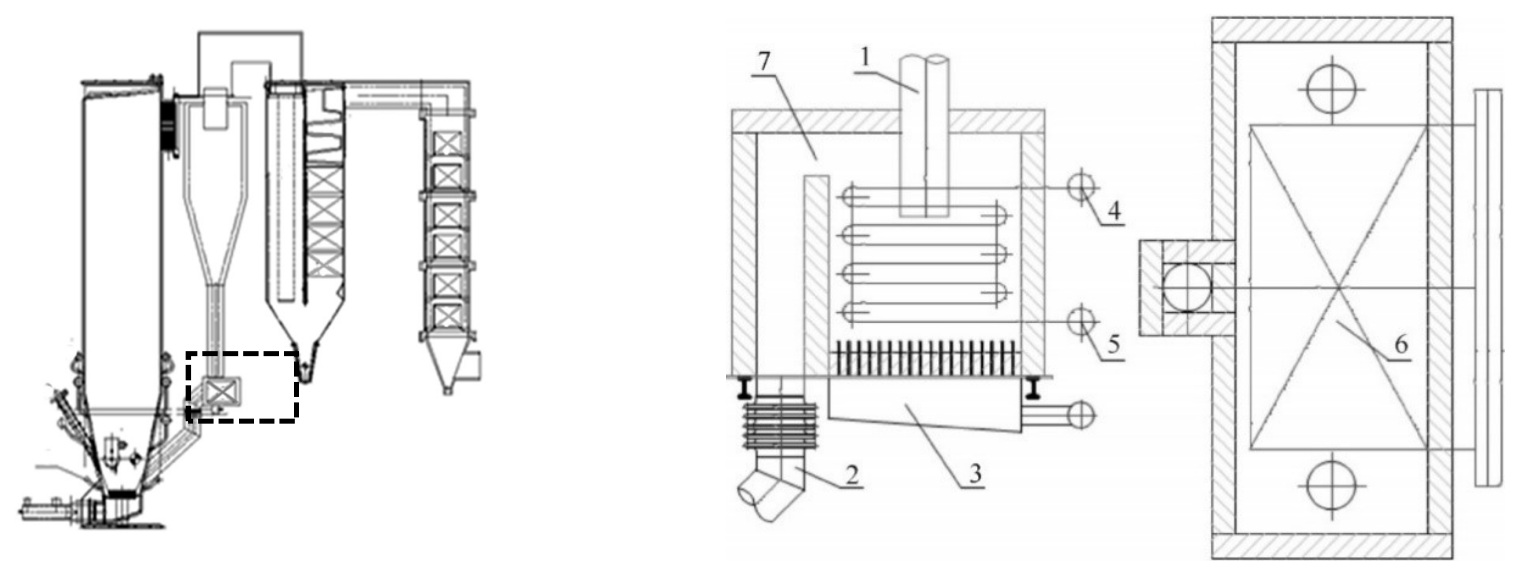

Figure 1. The figuration of EHE: 1—ash inlet 2-ash back 3-equalizing air chamber 4-high temperature superheater outlet header 5-high temperature superheater inlet header 6-high temperature superheater serpentine tube 7—ash back overflow hole.

The life cycle assessment (LCA) is a holistic evaluation methodology that quantifies all the environmental burdens of a product or service from the cradle to the grave throughout the life cycle [12]. The LCA has been widely applied in integrated waste management systems in recent years [13-15]. Dong [16] adopted the life cycle assessment to estimate the impacts of different flue gas treatment systems typically found in modern MSW incinerators. Hong [17] conducted a life cycle comparison of environmental performances from four available MSW treatment alternatives (CFB system, MG system, landfill and emitted gases used for power generation and landfill), indicating that CFB system behaved better than MG system, while landfill was the worst environmental option. The modified LCA integrated with an engineering economy for the design experiments [18] was associated with energy consumption, as well as life cycle cost [19], and energy, economy and society [20] was also conducted in the literature. However, the life cycle assessment of the advanced 
CFB incineration system equipped with the MBT and EHE is not yet studied and needs a comprehensive analysis, based on the on-site operational data.

The LCA is able to identify and quantify energy, material and waste emissions; however, as it is based on the first law of thermodynamics, it encounters many difficulties in application, especially when comparing different energy forms because it considers only quantity but not quality $[21,22]$. Exergy not only reflects both the quantity and quality of energy carriers by the first and second law of thermodynamics, but represents the value of natural resources too, by means of the unified evaluation standard. When integrated with the LCA framework, the exergetic life cycle assessment (ELCA) is proposed and measures the total exergy of natural resources extracted from the environment in a life cycle of a product or process [23,24]. Szargut [25] summarized the methods of calculating the cumulative exergy consumption (CExC) and introduced the cumulative degree of perfection (CDP) for the entire chain of production processes. The studies on cumulative exergy consumption indicators applied to the Ecoinvent database were conducted with the aim of convenient calculations [26]. Based on the concept of CExC, ELCA was applied to assess " $\mathrm{CO}_{2}$ zero-emission" energy systems [22], different sludge treatment techniques [27], and MSW gasification-based thermal treatments [21]. However, the advanced CFB incineration system equipped with MBT and EHE has not been assessed yet. Therefore, the ELCA should also be conducted. Recent studies recognized ELCA as a part of LCA representing the impact category of resources depletion and took environmental burdens into account via the abatement exergy of released pollutants $[19,21]$, while the land resources were not considered.

The resource value of land can be defined as the total natural potential net primary production (NPP) of a land area if it is not occupied by humans [28,29]. Due to the depletion of non-renewable resources and policy actions to mitigate climate change, an increased pressure on land as a resource is to be expected [30,31]. The ELCA is suggested to bring both abatement exergy and land use into consideration in its framework for a comprehensive and scientific evaluation.

The goal of this study is to compare the environmental impact, material and energy efficiency of three waste-to-energy cases by LCA and ELCA, in order to advise waste treatment. This study evaluated the environmental burdens and resource use efficiencies of the advanced CFB incineration system equipped with MBT and the EHE. The conventional CFB and MG incineration systems were compared with this advanced CFB system using the methods of environmental LCA and exergetic LCA. The two assumed process improvements, corresponding to whether semi-compost should be recycled as soil conditioner or sent to landfill sites, were modeled and compared with the current operation of this advanced CFB system. All the data used for the calculation were collected from real operational report and records, and the functional unit was unified as $1000 \mathrm{~kg}$ of raw MSW, and the plants selected were representative in China. The LCA was used to measure environmental burdens, while the ELCA quantified the relevant resource use efficiencies. Afterward, the considered ELCA results with land use were compared with the case of not taking land use into account. The final results could serve as the scientific basis for further developing advanced MSW incineration systems in the future.

\section{Methodology}

As guided by the International Organization for Standardization (standards 14040 series) [32], LCA consisted of four steps: goal and scope definition, life cycle inventory (LCI), life cycle impact assessment (LCIA) and interpretation. When collecting life cycle inventories, the environmentally relevant physical flows to and from the systems should be included. The LCA method, Recipe 2016, was used for environmental assessment in this study. Due to a more specific impact category of midpoint compared to endpoint, midpoint was chosen and analyzed. Six environmental impacts were considered: climate change, fossil depletion, human toxicity, ironizing radiation, particulate formation, and photochemical oxidant formation, because their midpoint impacts contributed more than $98 \%$ of the total 
impact while the influence of the remaining 11 indicators was too small to analyze. The negative value represented gains to the environment. The characterization factors were adopted from GaBi 8.0 software.

ELCA was proposed and developed by combining the concept of exergy analysis and environmental LCA. Consequently, the general framework of ELCA was recognized as identical compared to LCA [21]. The life cycle-based exergy analysis quantified the cumulative exergy consumption of a system from cradle to grave. Thus, ELCA could be supplemented as part of LCA [33], representing one impact category to assess resources consumption. Szargut [25] proposed cumulative exergy consumption (CExC) to measure ELCA [34]. CExC represented the total exergy of natural resources delivered to the system in all links of the production chain that started with resource exploitation and finally led to the product $[25,34]$.

In this study, the calculation of CExC was perfected and land use was taken into consideration. The natural potential net primary production (NPP), which was the amount of NPP a land area would produce if it was not occupied by humans $[28,29]$, could be used as a suitable proxy to represent the resource value of the land. Alvarenga [35] proposed and implemented a new framework to calculate exergy-based spatial explicit characterization factors (CF) for land as resources. The CExC of a system was calculated by summing all the CExC of life cycle inventories, while the CExC of certain LCI could be obtained from additive exergy of different natural resources, including land resources. The CExC efficiency $\left(\eta_{C E x C}\right)$ was defined as "the ratio of all CExC of the output products and input resources" and calculated as shown in Equation (1) [19]:

$$
\eta_{C E x C}=\frac{\left(\sum_{i} O_{i}\right)_{C E x C}}{\left(\sum_{j} I_{j}\right)_{C E x C}}=\frac{\left(O_{\text {useful }}\right)_{C E x C}}{\left(I_{M S W}+I_{\text {electricity }}+I_{\text {hydrated_lime }}+I_{\text {active_carbon }}+I_{\text {ammonia }}+I_{\text {diesel }}\right)_{C E x C}}
$$

where, " $I$ " represented the input flows, including MSW, electricity, hydrated lime, active carbon, titanium dioxide, ammonia, cement, diesel oil, and coal; " $O$ " referred to the output flows, which were different useful products, mainly electricity.

Based on LCI results and CExC method, cumulative degree of perfection (CDP) could be used to evaluate the degree of thermodynamic imperfections of the selected thermal conversion systems. CDP was proposed and defined as the ratio of exergy content of the products to the total CExC of the input energy and materials as presented in Equation (2) [36]:

$$
C D P=\frac{e_{X, \text { useful }}}{\left(I_{M S W}+I_{\text {electricity }}+I_{\text {hydrated_lime }}+I_{\text {active_carbon }}+I_{\text {ammonia }}+I_{\text {diesel }}\right)_{C E x C}}
$$

where, " $e_{X, \text { useful" }}$ " represented the exergy of the useful products.

In addition, ELCA could also be applied to assess the environmental impacts by taking into account the exergy consumption for the treatment of emissions to the environment [37]. Abatement exergy (AbatEx) was thus defined as "the internal exergy loss caused by the abatement of air emissions to an accepted limit for environment" [38]. Cornelissen [36] calculated the abatement exergy of $\mathrm{CO}_{2}$ at $5.86 \mathrm{MJ} / \mathrm{kg}$, which meant the exergy required to store $1 \mathrm{~kg}$ of $\mathrm{CO}_{2}$ in a depleted oil well at $8 \mathrm{MPa}$ was $5.86 \mathrm{MJ}$. The abatement exergy of $\mathrm{SO}_{2}$ and $\mathrm{NO}_{x}$ was 57.0 and $16.0 \mathrm{MJ} / \mathrm{kg}$, respectively [36]. The development of the abatement exergy calculated for air emissions was limited due to the lack of available data in the literature [38]. Therefore, the abatement exergy was subtracted from the output CExC flows, and the indicator of AbatCExC efficiency ( $\left.\eta_{A b a t C E x C}\right)$ is proposed in Equation (3) [36]:

$$
\eta_{\text {AbatCExC }}=\frac{\left(\sum_{i} O_{i}\right)_{C E x C}-\text { AbatEx }}{\left(\sum_{j} I_{j}\right)_{C E x C}}=\frac{\left(O_{\text {useful }}\right)_{C E x C}-\text { AbatEx }}{\left(I_{M S W}+I_{\text {electricity }}+I_{\text {hydrated_lime }}+I_{\text {active_carbon }}+I_{\text {ammonia }}+I_{\text {diesel }}\right)_{C E x C}}
$$

where "AbatEx" represented the abatement exergy required for treating air emissions, mainly $\mathrm{CO}_{2}, \mathrm{SO}_{2}$ and $\mathrm{NO}_{x}$. 


\subsection{System Boundary}

Figure 2 provided an overview of the system boundary and flow charts of the three typical MSW incineration systems. The evaluation started with the collection of MSW into the incineration plant and ended with the emissions of the plant to air, water and soil. The consumed reagents, water and electricity were traced back to their production processes; therefore, the indirect environmental impacts or resource use efficiency could be obtained. The produced waste water was treated inside the plant and fly ash was landfilled after stabilization. The inert materials sorted from raw waste were landfilled as well. Useful resources like ferrous and aluminum metals were recycled. Furnace slags were considered as valuable resource for substituting bricks and the electricity was recovered to electricity grid of China. Optionally, the produced semi-compost could be used as soil conditioner substituting a certain amount of phosphate fertilizer.

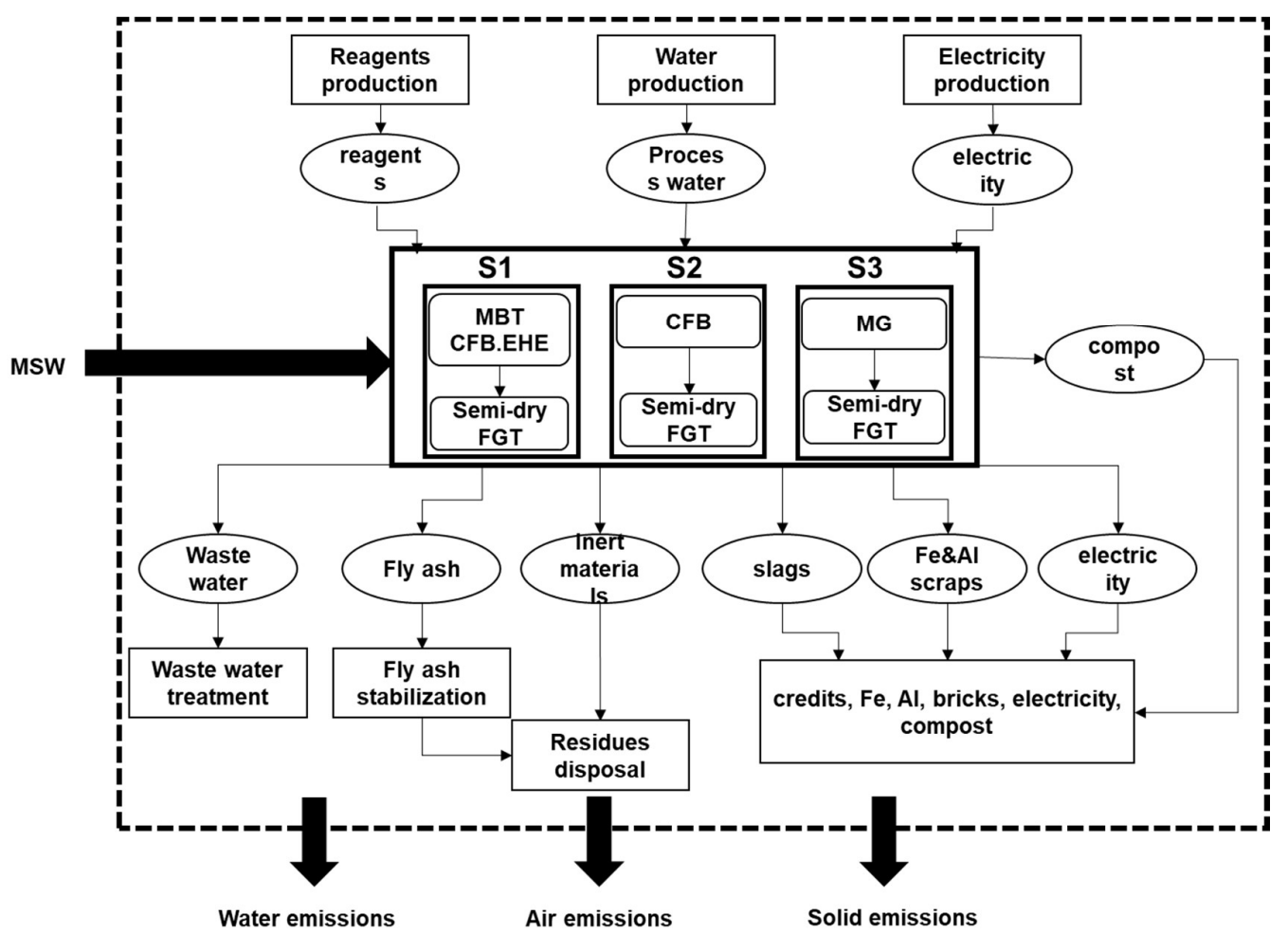

Figure 2. System boundary and flow charts of the considered incineration systems.

In this study, five MSW incineration scenarios were considered. The advanced CFB incineration system equipped with MBT and the EHE system was considered as the base system (S1). For this advanced CFB system, two general downstream semi-compost utilities were investigated by using the semi-compost as soil conditioner $\left(\mathrm{S}_{\text {soil conditioner }}\right)$ or by landfilling the semi-compost ( $\mathrm{S}_{\text {landfill }}$ ). $\mathrm{S} 2$ represented the conventional CFB incineration system and S3 was the current, prevailing MG incineration system. The specific descriptions of the five scenarios can be found in the part "Specific descriptions of the five scenarios", Figure S1 and Figure S2 of the online Supplementary Materials. Based on the proposed

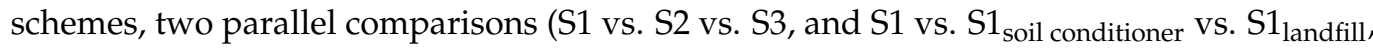
respectively) were conducted from the environmental burdens and exergetic resource use efficiencies using LCA and ELCA.

\subsection{Description of the Proposed Scenarios}

The qualitative analysis of life cycle inventory data determined directly the effectiveness of an LCA or ELCA. In this study, data used for calculation were mainly from on-site operational records, except for the parts of ELCA and the potential optimization 
assessment. The typical values for characterization of MSW, which were used for the considered scenarios, are specified in Table 1. Zhou [39] reviewed the characteristics of physical and chemical composition of MSW in China; the mean value was referred to in this study as shown in Table 1. It appeared that the MSW of 5 scenarios was similar to the Chinese average level.

Table 1. Characteristics of MSW.

\begin{tabular}{|c|c|c|c|c|c|c|c|c|}
\hline & \multicolumn{8}{|c|}{ MSW Characteristics (wt.\%, as Received Basis) } \\
\hline & Carbon & Hydrogen & Nitrogen & Sulfur & Chloride & Moisture & Ash & $\mathrm{LHV}^{\mathrm{a}}(\mathrm{MJ} / \mathrm{kg})$ \\
\hline Chinese average level & 16.69 & 2.3 & 0.45 & 0.11 & 0.37 & 48.12 & 22.6 & 5.337 \\
\hline S1: advanced CFB & 17.3 & 2.59 & 0.3 & 0.2 & 0.45 & 49.4 & 18.94 & 5.851 \\
\hline S2: CFB incineration & 16.4 & 2.28 & 0.25 & 0.13 & 0.44 & 48.73 & 22.6 & 5.224 \\
\hline S3: MG incineration & 16.9 & 2.43 & 0.3 & 0.13 & 0.42 & 50.97 & 20.44 & 5.67 \\
\hline
\end{tabular}

a LHV: lower heating value.

\subsubsection{S1: Advanced Circulating Fluidized Bed Incineration System in Zibo}

S1 was the advanced type of circulating fluidized bed in China, supported by a complex mechanical biological treatment system for treating raw waste before combustion, was designed to reach a relative high steam parameters level $\left(520^{\circ} \mathrm{C}, 79 \mathrm{bar}\right)$. Mechanical biological treatment (MBT) of mixed streams is becoming increasingly popular as a method for treating MSW [40]. The outputs of MBT plants were: recyclable (mostly metals) and compostable materials, refuse-derived fuel (RDF) and a fraction of residuals. Differently, the selected plant, S1, took MBT as a part to treat raw waste, the advantage was that after biological reaction and mechanical screening, RDF with low water content and high calorific value could be obtained, together with useful resources, such as ferrous and non-ferrous (aluminum) metals, as well as semi-compost burnt in incinerator. MBT is aerobic and more details on MBT can be found in the Supplementary Materials. The reason why S1 could reach relatively high steam parameters was that the final steam superheater took place in the heat exchangers located in the solids returns, as shown in Figure 3, so that they prevented the contact between high-temperature flue gas and heat transfer. As a result, the configuration not only guaranteed a high temperature and pressure steam but also reduced the fouling and corrosion of the super heat transfer surfaces. As for the air pollution control system, S1 was composed of selective non-catalytic reduction technology, semidry-dry scrubber, active carbon absorption, as well as bag house filter.

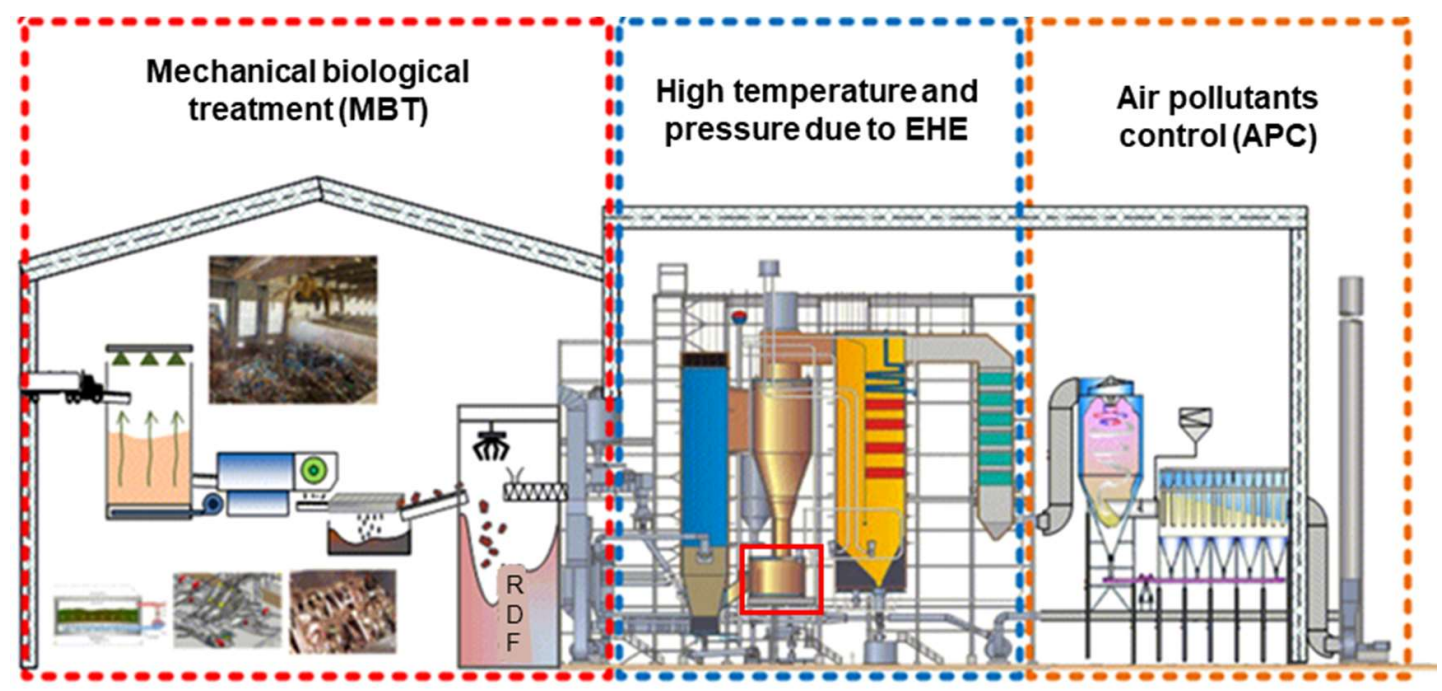

Figure 3. The technological process of advanced CFB incineration system. 


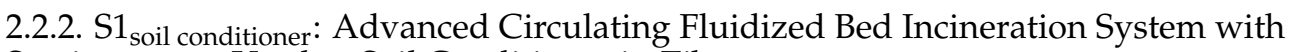
Semi-compost Used as Soil Conditioner in Zibo

Generally, one potential advantage of MBT technology over the waste incineration plant was the production of semi-compost that could be used as phosphate fertilizer or soil conditioner, which was good for soil and planting. Thus, $\mathrm{S} 1_{\text {soil conditioner }}$ with the utilization of semi-compost sorted from MBT as soil conditioner for farmland, was also proposed and evaluated in this study, even though its commercial application is still under research.

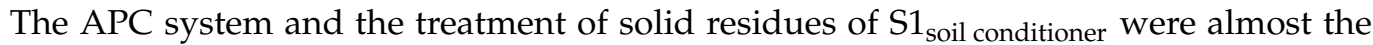
same as $\mathrm{S} 1$.

\subsection{3. $\mathrm{S1}_{\text {landfill: }}$ Advanced Circulating Fluidized Bed Incineration System with Landfill} Disposal of Semi-Compost in Zibo

$S 1_{\text {landfill }}$ was represented as a variant of the advanced CFB system, which was set to send the produced semi-compost to landfill site in Zibo. The landfill disposal of semicompost was chosen because, on the one hand, semi-compost sorted from the MBT system had a high content of ash which could cause adverse effects to the combustion; on the other hand, semi-compost could be used for fertilizer/soil conditioner, which was not previously

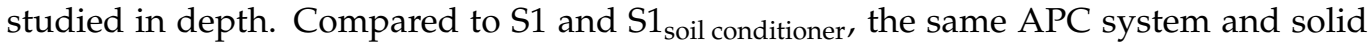
residues treatment methods were adopted in $S 1_{\text {landfill }}$.

\subsubsection{S2: Conventional Circulating Fluidized Bed Incineration System in Hangzhou}

S2 represented the conventional circulating fluidized bed MSW incineration system in Hangzhou, China, with $485^{\circ} \mathrm{C}$ and 53 bar boiler parameters. Available from 2015, this 24 MW system handles approximately 400,000 tons of MSW per year. Though S2 also had an external heat exchanger to produce superheat steam, the produced steam was much lower than S1 $\left(485^{\circ} \mathrm{C}, 53\right.$ bar for S2 comparing to $520^{\circ} \mathrm{C}, 79$ bar for S1), and S2 had no pretreatment for raw waste. In this study $\mathrm{S} 2$ were regarded as conventional CFB systems. In order to control the emission of flue gas pollutants, the selective non-catalytic reduction (SNCR) equipment and selective catalytic reduction (SCR) system were installed; flue gas treatment facilities composed of a semidry scrubber, active carbon absorption and bag house filters were also used [20].

\subsubsection{S3: Moving Grate Incineration System in Zhuji}

S3 reflected the MG incineration system in Zhuji, China, which was built to substitute old CFB incineration plant for the improvement of technology and environment protection. The plant based on mechanical moving grate (MG) for the production of electricity (24 MW), and S3 was just a half of completion of the whole construction. The selected MG system, with an annual capacity of $147,782 \mathrm{t}$, was assumed to be in operation for 30 years as designed. A main advantage of the MG incinerator was its capacity to the treat unsorted waste [41]. Heat recovery steam generated superheated steam (450 ${ }^{\circ} \mathrm{C}, 53$ bar) with the utilization of heat from flue gas, and steam forced the turbine generator to produce electricity. Regarding air pollution control (APC) systems, S3 was equipped with semi-dry flue gas treatment system (SNCR-SCR, semidry-dry scrubber, active carbon absorption, and bag house filter).

\subsection{Life Cycle Inventory Analysis}

The qualitative life cycle inventories used for calculating LCA and ELCA results were similar, mainly due to the on-site operational records, supplemented by the literature and standard regulations. As for the semi-compost sorted from the MBT system shown in Supplementary Table S1, the Chinese national regulation standard shown in Supplementary Table S2 was used to estimate its feasibility of soil conditioner. According to testing results, the $\mathrm{As}, \mathrm{Cd}, \mathrm{Pb}, \mathrm{Cr}$ and $\mathrm{Hg}$ content of the semi-compost reached $0.003 \%, 0.0006 \%, 0.003 \%$, $0.007 \%$, and 0 , respectively. Thus, the regulation was satisfied and the semi-compost could be used as soil conditioner substituting phosphate fertilizer for compost, in the case of this 
study. Considered in the calculations as the category "offset", $32.5 \mathrm{~kg}$ of compost could replace $1 \mathrm{~kg}$ of commercial phosphate fertilizer.

Based on the collected data and assumptions, the inventory data was summarized in Supplementary Table S3, the input and output materials/energy flows were included, and the functional unit was set as one ton of raw MSW. In the appliance with the attributional LCA approach, a mix of energy sources in China were used (63.0\% fossil fuel, $16.9 \%$ hydropower, $10.4 \%$ wind power, $7.2 \%$ solar power and $2.5 \%$ nuclear power). The fossil fuel mix used here was the combination of $70 \%+$ coal, $10 \%+$ oil and $10 \%+$ natural gas in Chinese power plants.

It was obvious that the emission of $\mathrm{NO}_{\mathrm{x}}$ in the conventional CFB system (S2) and MG system (S3) was slightly lower than the advanced CFB systems (S1, $1_{\text {soil conditioner }}$ and $\left.S 1_{\text {landfill }}\right)$. The reason for this was mainly due to the use of SCR technology in S2 and S3.

The background data of ECLA are listed in Supplementary Table S4, and the CExC of materials/energy and the abatement exergy of $\mathrm{CO}_{2}, \mathrm{SO}_{2}, \mathrm{NO}_{x}$ were included. The NPP of materials/energy were calculated according to the area of land use and the relevant characterization factor (CF) of the land resources. According to the study of Alvarenga [35], the average CFs were 16.0, 26.5, 19.8 and $18.7 \mathrm{MJ} / \mathrm{m}^{2}$.year for China, Germany, the USA and Europe, respectively. The chemical exergy of MSW could be calculated by Equations (4) and (5) [42]:

$$
\begin{gathered}
e=\beta \times L H V_{M S W} \\
\beta=\frac{1.0412+0.216 H / C-0.24990 / C \times(1+0.7884 H / C)+0.045 N / C}{1-0.30340 / C}(O / C \leq 2.67)
\end{gathered}
$$

\section{Results and Discussion}

\subsection{Environmental Life Cycle Assessment}

In order to identify the key substances and corresponding stages, the six most important characterized environmental impacts were studied here, including climate change (CC), fossil depletion (FD), human toxicity (HT), ironizing radiation (IR), particulate formation (PF), and photochemical oxidant formation (POF) (Figure 4). The results showed that $\mathrm{S} 1$ exhibited lower potential effects than S3, except for the impact of FD, while the potential effects were completely better than the S2 system. As presented in Figure 4, the impact category of FD caused by S1 reached the value of $-2.07 \mathrm{~kg}$ oil equivalent, higher than the S3 system ( $-3.62 \mathrm{~kg}$ oil-equivalent). The reason for this was mainly attributed to the additional consumption of electricity and diesel for the MBT system pre-treating raw MSW. As mentioned in the Supplementary Materials, the internal electricity consumption rate of S1 increased to $24.9 \%$, while approximately two thirds of the internal power consumption was used to operate the MBT system. Additionally, S3 produced many furnace slags (200 kg for S3 compared to $81.7 \mathrm{~kg}$ for S1), which could be used as a substitution for bricks. The material recovery of S3 avoided lots of indirect environmental damages caused by high-pollution industry, such as bricks production. As a result, the environmental saving from slags and the produced electricity of S3 was proven to be higher than the savings from the energy /materials recovered of S1. The impact category of FD caused by S2 increased to $28.2 \mathrm{~kg}$ oil equivalent as a positive value, indicating the obvious damage to the environment. According to the life cycle inventory data from Supplementary Table S3, it was obvious that $\mathrm{S} 2$ consumed large quantities of coal and diesel to complete the ignition and starting up procedure of the circulating fluidized bed boiler. The higher the amount of electricity recovered and recycled resources were, the higher the gains in environmental protection. The advanced CFB system (S1) performed better than S3 in all cases, mainly due to the higher electricity generation efficiency ( $28 \%$ for S1 comparing to approximately $20 \%$ for S3). The recycled ferrous and non-ferrous metals from the MBT system were seen as credits which helped S1 achieve a better environmental score. 


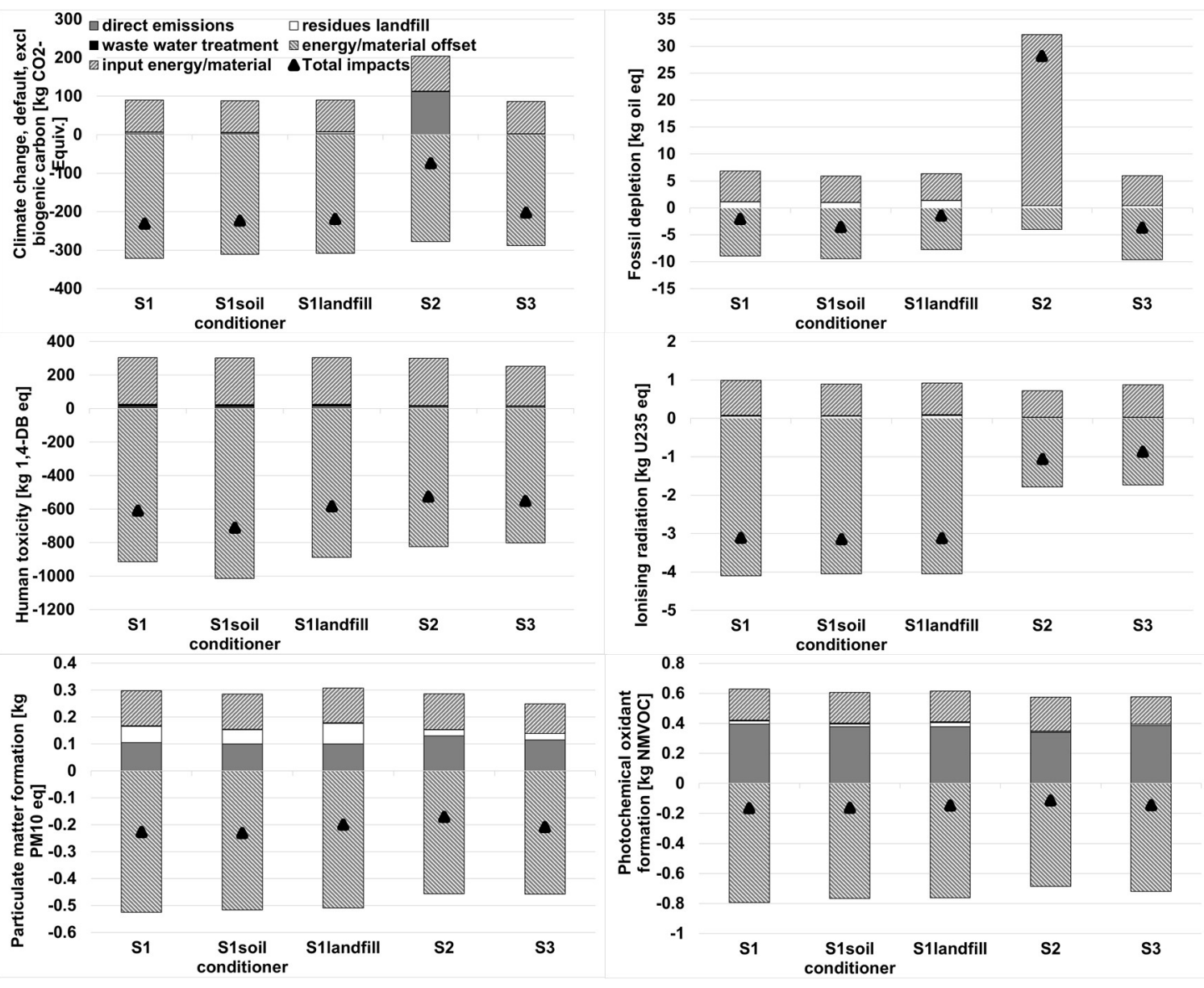

Figure 4. Characterized environmental impacts of the considered systems.

The conventional CFB system (S2) consumed more electricity, coal and diesel than the MG system (S3) (89.8 kWh-electricity, $41.8 \mathrm{~kg}$-coal and $2.06 \mathrm{~kg}$-diesel for S2 comparing to $76 \mathrm{kWh}$-electricity, $0 \mathrm{~kg}$-coal and $0.25 \mathrm{~kg}$-diesel for S3), which increased not only the indirect environmental damages from the relevant production of energy/materials but also the direct emissions, such as fossil $\mathrm{CO}_{2}$. Thus, $\mathrm{S} 2$ exhibited the highest impact for almost every category.

Among the five different life cycle stages of the impact contributors, the impacts caused by waste water treatment were relatively small, accounting for less than $1.2 \%$ of the total environmental burdens, except for the offset from the energy/material recovered. The results were based on the reality that the consumption of reagents for cleaning waste water in power plants was not available. In the waste water treatment stage, the waste water from the operational plants and the leachates from the solid residues landfill were first treated inside the plant and then sent to the waste water treatment plant for deep-cleaning; thus, if the reagents used for treating water were not taken into consideration and only the limited water emissions (like $\mathrm{COD}, \mathrm{BOD}$ and $\mathrm{NH}_{3}-\mathrm{N}$ ) were considered, the environmental impacts generally appeared as a very small value, proportional to the amount of waste water treated. In general, the impacts from the waste water treatment of S1 exhibited higher values than S2 and S3, and the drawbacks mainly resulted from a higher production of waste water from complex pretreating systems and leachates from both biological reactions and residues landfill.

The stage of direct emissions played an import role in PF and POF due to pollutants such as $\mathrm{SO}_{2}, \mathrm{NO}_{\mathrm{x}}$, and related particles. In the $\mathrm{S} 2$ scenario, the stack $\mathrm{CC}$ emission was the highest; subsequently, $\mathrm{CO}_{2}$ was found to be the most crucial contributor, as shown in Supplementary Table S3. $\mathrm{CO}_{2}$ in the flue gas was a product from the consumption of 
coal and diesel for combustion or diesel for transportation. However, the CC burdens of S2 could be negated by the environmental credits from the recovery of energy/materials leading to a net environmental saving.

Overall, the environmental improvement of the advanced CFB system (S1) verified a significant role of the external heat exchanger (EHE) located in solid returns, as well as the MBT system, which could not only recycle useful resources like ferrous and non-ferrous metals, but also allowed a higher steam parameter to increase the overall energy efficiency. Additionally, the debugging and stable operation of MBT in an advanced CFB incineration system were of vital importance to its entire environmental performance.

A parallel comparison between the three advanced CFB scenarios $\left(\mathrm{S} 1, \mathrm{~S} 1_{\text {soil conditioner }}\right.$ and $S 1_{\text {landfill }}$ ) was also conducted. It appeared that the incineration plant under the condition of $\mathrm{S} 1_{\text {soil conditioner }}$ performed the best when compared to $\mathrm{S} 1$ and $\mathrm{S} 1_{\text {landfill }}$, except for the impact category of CC. As presented in Figure 4, the impact category of CC caused by $\mathrm{S} 1_{\text {soil conditioner }}$ reached the value of $-223 \mathrm{~kg} \mathrm{CO}_{2}$ equivalent and was found to be slightly higher than $\mathrm{S} 1$ system ( $-231 \mathrm{~kg} \mathrm{CO} 2$ equivalent). The environmental savings of using semi-compost as a soil conditioner could not negate the electricity credits by using semicompost as a fuel, as the resulting $\mathrm{S} 1_{\text {soil conditioner }}$ achieved a lower score for the impact of $\mathrm{CC}$ than S1. The semi-compost sorted from the MBT system appeared to have a high ash content and a low calorific value. During the combustion in the incineration, a lot of fly ash was produced and the consumption of relevant reagents increased so that it was not be suitable for combustion to generate power. $\mathrm{S} 1_{\text {soil conditioner }}$ recycled the semi-compost as a soil conditioner which could be seen as a certain amount of phosphate fertilizer, preventing the large environmental damages from producing phosphate fertilizer, as well as reducing the use of the chelating agent for fixing fly ash. So the environmental savings (FD, HT, $\mathrm{IR}, \mathrm{PF}$ and $\mathrm{POF}$ ) proved higher than the credits from the electricity produced by the semicompost in $\mathrm{S} 1$. By contrast, $\mathrm{S}_{\text {landfill }}$ exhibited the highest impacts for all categories (CC, FD, HT, IR, PF and POF). S1 landfill lacked the advantage of environmental credits via the electricity recovered as compared to $\mathrm{S} 1$ ( $371 \mathrm{kWh}$ per $\mathrm{t}-\mathrm{MSW}$ for $\mathrm{S} 1_{\text {landfill }}$ comparing to 381 $\mathrm{kWh}$ per t-MSW for $\mathrm{S} 1$ ). Additionally, the $\mathrm{S}_{1}$ landfill semi-compost was seen as containing useless residues and was sent to the landfill sit; therefore, the total amount of residues for landfill increased and more energy /materials (like HDPE and clay) were consumed for this purpose, resulting in an increase in the indirect environmental burdens, as well as the direct emissions, i.e., $\mathrm{NH}_{3}$ and $\mathrm{CH}_{4}$.

As for the whole environmental performance, Figure 5 illustrates the normalized environmental impacts of different scenarios from five different life cycle stages: direct emissions, residues landfill, waste water treatment, energy/material offset, and input energy/material. From Figure 5, the results revealed that the advanced CFB incineration system (S1) exhibited lower environmental burdens as compared to the conventional CFB (S2) and MG (S3) systems. All of the three systems appeared to have negative values, which actually indicated net environmental savings. The most important two stages contributing to the net environmental impacts of the systems, in the order of contribution, were energy/materials offset and input energy/materials. Meanwhile, the total of the remaining impacts came from direct emissions, residues landfill and waste water treatment and only accounted for 17 25.4\% of the impacts from input energy /materials, or $4.9 \sim 7.8 \%$ of the impacts from energy /materials offset.

The impact from the energy/material offset of S1 reached -1.104 person equivalent, and was found to be more significant than S2 ( -0.979 person equivalent) and S3 $(-0.964$ person equivalent). The reason for this was mainly attributed to the use of the MBT pre-treatment system and the EHE in the solids returns; the former recycled useful resources like ferrous and non-ferrous (aluminum) metals. The latter allowed the boiler to employ higher steam parameters than those of a conventional waste boiler $\left(520^{\circ} \mathrm{C}\right.$, 79 bar in comparison to $400{ }^{\circ} \mathrm{C}, 40 \mathrm{bar}$ in conventional MSW incineration plant [43] so that the electricity generation efficiency improved effectively (electricity production efficiency of $28 \%$ ). As for the impact from the input energy/materials, the value of S1 was lower 
than S2 by approximately 0.02 person equivalent, but higher than S3 by about 0.05 person equivalent, which was negligible when compared to the difference of impact from the energy/materials offset. When comparing S2 with S3, and S3 with a lower impact from direct emissions and input, the energy/materials exhibited higher net environmental savings than S2, which lead to the most inferior to normalized environmental performance. Among the advanced scenarios ( $\mathrm{S} 1, \mathrm{~S} 1_{\text {soil conditioner }}$ and $\left.\mathrm{S} 1_{\text {landfill }}\right), \mathrm{S} 1_{\text {soil conditioner }}$ exhibited the best normalized environmental performance due to the use of a semi-compost from the MBT system as soil conditioner, substituting phosphate fertilizer. This finding, that the recovery of materials improves the environmental performance of an MSW management system, is also supported by other authors [44-47].

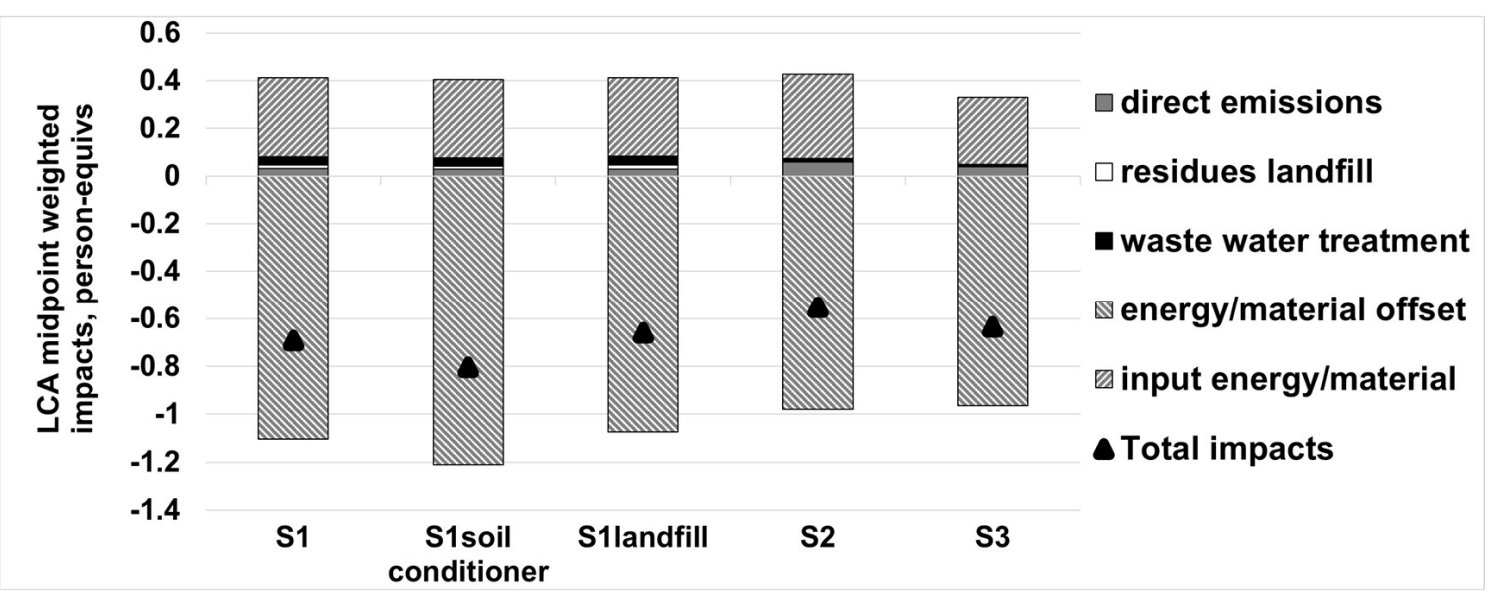

Figure 5. Normalized environmental impacts of the considered scenarios.

The conclusion from the characterization of the environmental impacts and normalized environmental impacts showed that the environmental performance of the advanced CFB scenarios varied in a descending order: $S 1_{\text {soil conditioner }}>\mathrm{S} 1>\mathrm{S} 1_{\text {landfill }}$ ("> $>$ " means the former system is superior to the latter one). The results clearly indicated the advantages of using semi-compost as a soil conditioner rather than fuels. Therefore, it was recommended that recycle or reuse should always be considered superior to disposal or landfill.

Moreover, the different sensitivity factors of the inputs/outputs were calculated for S1. The sensitivity factor was the ratio of the result change to the input/output variable change. The net electricity sensitivity factor for the normalized results, CC, FD, HT, IR, and POF, were $-1.11,-1.17,-0.98,-0.84,-0.89$, respectively, meaning the power generation efficiency had a great influence on the environment. Therefore, the efficiency improvement was very necessary. The materials were recycled from MBT (metal, brick and fertilizer) and the sensitivity factors were $-0.03,-0.01$ and -0.04 , respectively. This indicated that fertilizer was the most environmentally friendly output among the recyclable materials. Again, the $S 1_{\text {soil conditioner }}$ produced the highest net electricity power and recycled compost, and so it had the best performance.

\subsection{Exergetic Life Cycle Assessment}

Figure 6 presents the cumulative exergy consumption (CExC) efficiency and AbatCExC efficiency of different scenarios. The CExC efficiency $\left(\eta_{C E x C}\right)$ of the considered scenarios in descending order were as follows: $65 \%$ of S1 > 59\% of S3 > 51\% of S2, and $68 \%$ of $S 1_{\text {soil conditioner }}>65 \%$ of $S 1>63 \%$ of $S 1_{\text {landfill, }}$, respectively. If the cumulative exergy consumption of land resources was considered, the ranking results were maintained but the values of each scenario increased; these values were $66 \%, 69 \%, 65 \%, 52 \%$, and $60 \%$ for $\mathrm{S} 1, \mathrm{~S} 1_{\text {soil conditioner, }} \mathrm{S} 1_{\text {landfill, }} \mathrm{S} 2$, and $\mathrm{S} 3$, respectively. The increments of $\eta_{\mathrm{CExC}}$ seemed reasonable because the main contributor of the difference was the amount of electricity, while all five scenarios exhibited a net recovery of electricity. The input cumulative exergy 
consumption of electricity increased by less than $45 \mathrm{MJ}$ per t-MSW if the CExC of land resources was taken into consideration, while the output cumulative exergy consumption of electricity increased by more than 160 MJ per t-MSW, approximately four times the input value. Considering that the values of $\eta_{C E x C}$ from the five scenarios were higher than the relevant performances without considering land use, this reflected that the framework which brought land use into the CExC was a more general evaluation of the cumulative exergy consumption of a process/system.
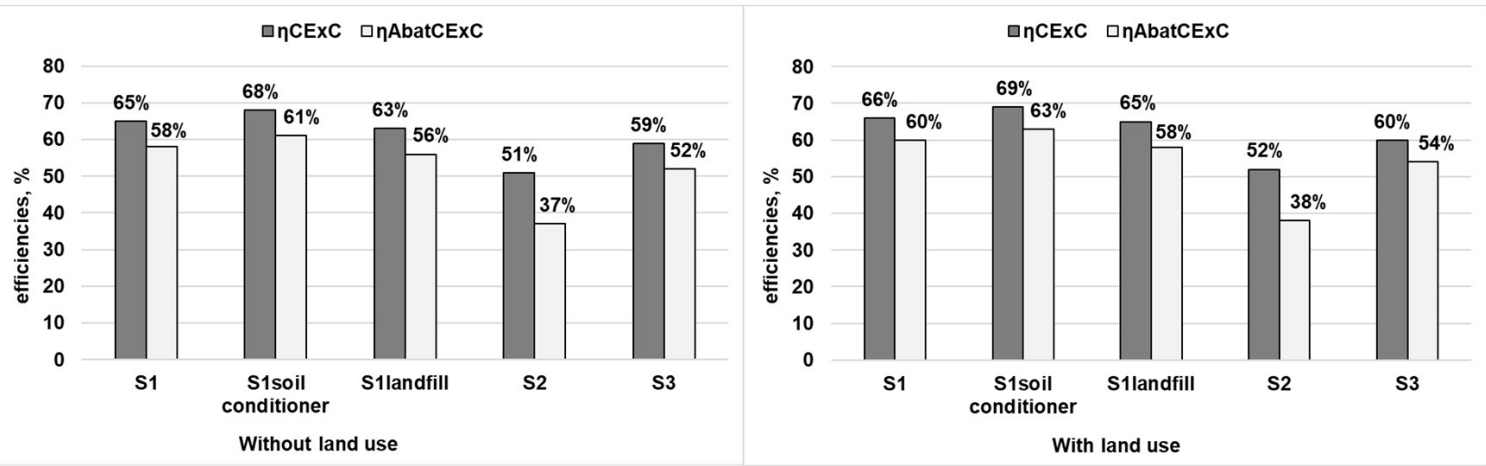

Figure 6. Cumulative exergy consumption (CExC) efficiency and AbatCExC efficiency of the considered systems.

In general, the advanced CFB system (S1) was found to be more resource-efficient than the conventional CFB and MG system (S2 and S3). This can be explained from the perspective of the energy/materials recovered. If the MBT system and the EHE were used in the MSW CFB incineration plant, the output-useful resources increased, including ferrous and non-ferrous metals, the substitution of bricks, the produced electricity, and even the substitution of a soil conditioner or phosphate fertilizer for semi-compost. Therefore, the sum of the output, CExC, was higher than the conventional MSW incineration systems which could only achieve the recovery of electricity with a lower efficiency. Based on the results of the ELCA, the output, CExC, of the advanced CFB (S1) reached a value of $5365 \mathrm{MJ}$ per t-MSW, while the value of S2 and S3 appeared to show lower values of $4338 \mathrm{MJ}$ and $4593 \mathrm{MJ}$, respectively. On the contrary, the conventional CFB system (S2) had the lowest $\eta_{\mathrm{CEx}}$, which was due to the highest consumption of coal and diesel used for keeping the stable burning (1410 MJ of coal and diesel for S2, compared to less than 50 MJ for S1, and S3).

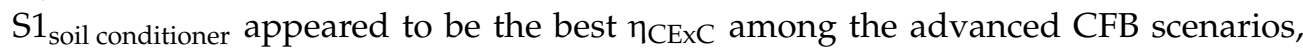
regardless of whether the NPP of land resources was considered or not. There were two

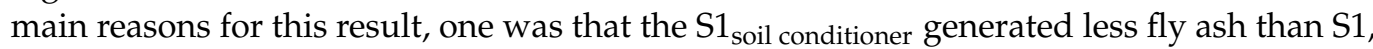
leading to a lower consumption of the chelating agent. Additionally, the input, CExC, of the chelating agent decreased dramatically from $468 \mathrm{MJ}$ of S1 to $343 \mathrm{MJ}$ for S1 $1_{\text {soil conditioner. The }}$ other result was that the $S 1_{\text {soil conditioner }}$ recycled the semi-compost which could increase the CExC of $364 \mathrm{MJ}$, leading to the total CExC of the useful outputs reaching a higher value

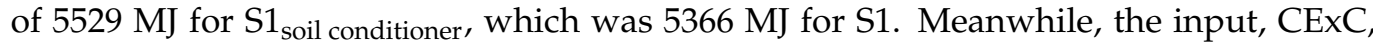
reached the lower value of $8181 \mathrm{MJ}$ for $\mathrm{S} 1_{\text {soil conditioner }}$ and $8306 \mathrm{MJ}$ for $\mathrm{S} 1$. As a result, the calculated $\eta_{\mathrm{CExC}}$ of $S 1_{\text {soil conditioner }}$ was higher than $\mathrm{S1}$, while among the advanced $\mathrm{CFB}$ systerm, $\mathrm{S} 1_{\text {landfill }}$ performed the worst due to the disposal of useful semi-compost. To be more specific, the output, $\mathrm{CExC}$, of $S 1_{\text {landfill }}$ reached the value of $5165 \mathrm{MJ}$ which was much lower than both $\mathrm{S} 1$ and $S 1_{\text {soil conditioner. }}$

With regard to the abatement exergy and AbatCExC efficiency ( $\left.\eta_{\text {AbatCExC }}\right)$ of different scenarios, the results showed that $58 \%, 61 \%, 56 \%, 37 \%$, and $52 \%$, of the AbatCExC efficiency were achieved by $\mathrm{S} 1, \mathrm{~S} 1_{\text {soil conditioner }}$ and $\mathrm{S} 1_{\text {landfill, }}, \mathrm{S} 2$, and $\mathrm{S} 3$, respectively. When taking land use into consideration, the values of the AbatCExC efficiency of S1, S1 $1_{\text {soil conditioner }}$ and $\mathrm{S}_{\text {landfill }}, \mathrm{S} 2$, and S3 reached $60 \%, 63 \%, 58 \%, 38 \%$, and 54\%, respectively. Similar to the difference calculated from the $\mathrm{CExC}$ efficiency, the produced electricity played an import 
role in calculation, which again revealed that the framework of the ELCA should take land use into consideration. The values of the AbatCExC efficiency were lower than the relevant CExC efficiency, due to the subtraction of the abatement exergy from the total output CExC. It was obvious that $\mathrm{S} 2$ consumed large amounts of coal and diesel and emitted the highest $\mathrm{CO}_{2}$ pollutants into the atmosphere as compared to $\mathrm{S} 3$ and $\mathrm{S} 1$, so the abatement exergy loss of S2 exhibited the highest value at $1200 \mathrm{MJ}$, while the abatement exergy of other systems (S1, and S3) was no more than $550 \mathrm{MJ}$. Additionally, the CExC efficiency and AbatCExC efficiency of S2 were the worst. With respect to the advanced CFB system (S1) and MG system (S3), S1 showed a better performance of AbatCExC efficiency than the conventional MG system, which could also be explained from the perspective of the energy/materials balance. Though the results of the AbatCExC efficiency seemed reasonable, the abatement exergy for the other emissions, especially heavy metals and dioxins, was lacking and the values were unavailable to obtain. Therefore, only the abatement exergy of $\mathrm{CO}_{2}, \mathrm{SO}_{2}$ and $\mathrm{NO}_{\mathrm{x}}$ was considered in this study. However, the model and results could be easily updated if the data became available in the near future.

A parallel comparison about AbatCExC efficiency for the three advanced CFB scenarios ( $\mathrm{S} 1, \mathrm{~S} 1_{\text {soil conditioner }}$ and $\mathrm{S} 1_{\text {landfill }}$ ) was also conducted. It appeared that $\mathrm{S} 1$ led to an inferior performance than $S 1_{\text {soil conditioner, }}$, and $S 1_{\text {landfill }}$ exhibited the worst result. As mentioned, $\mathrm{S}_{\text {soil conditioner }}$ recycled semi-compost as a soil conditioner substituting phosphate fertilizer, which brought more gains of the output, CExC, than the CExC of the electricity recovered by semi-compost combusting in S1. Moreover, when taking abatement exergy into account, the consumed AbatCExC of $\mathrm{S}_{\text {soil conditioner was lower than that }}$ $\mathrm{S} 1$ due to less $\mathrm{CO}_{2}, \mathrm{SO}_{2}$ and $\mathrm{NO}_{\mathrm{x}}$ emissions, indicating the material recovery as using a soil conditioner was a good method for the efficient utilization of semi-compost sorted from the MBT system. This was similar to the result and analysis of the CExC efficiency that $\mathrm{S1}_{\text {landfill }}$ performed the worst once more in the AbatCExC efficiency compared to $\mathrm{S} 1$ and $\mathrm{S} 1_{\text {soil conditioner }}$.

The details, regardless of whether land use is considered, of the AbatCExC efficiency for different scenarios were calculated and presented in Supplementary Table S5 and the value of the AbatCExC efficiency decreased comparative to the relevant CExC efficiency. However, the changing tendency was similar.

The CDP of the considered scenarios reflected that the consumed energy/materials derived from natural resources were recovered by the final useful products (mainly electricity). If land resources were seen as natural resources and the NPP of land use was embodied in the ELCA, the calculated CDP would be declined comparative to CDP from the conventional ELCA framework. Though the changing tendency may not change too much, the method considering land use was indeed a more scientific and holistic framework, which was efficient in analyzing all kinds of energy or material production processes, especially those with much land use, such as landfill site and industrial parks. From the definition, it was observed that CDP declined comparative to the CExC efficiency, which was the ratio of the total amount of CExC of the output and input flows. The CDP of the five selected scenarios, as shown in Figure 7, presented similar changing tendencies to the observation of the CExC efficiency. The value of CDP reached $19 \%, 19 \%, 18 \%, 16 \%$, and $18 \%$ for $\mathrm{S} 1, \mathrm{~S} 1_{\text {soil conditioner, }} \mathrm{S}_{1 \text { landfill }}, \mathrm{S} 2$ and $\mathrm{S} 3$, respectively, while the values were slightly lower when land use was considered. The results and analysis of the CDP ranking were similar to the CExC efficiency ranking, where the advanced CFB system (S1) was superior to the conventional CFB (S2), and the MG (S3) system and conventional CFB (S2) system had the lowest efficiency.

As the CDP indicates the thermodynamics perfection and the degree of the renewability of a system or a process, as well as quantifying the energy utilization efficiency at a life cycle level [21], the advanced CFB system (S1) showed a higher thermodynamics perfection and degree of renewability. S2 showed the lowest thermodynamics perfection and degree of renewability because of the large amounts of coal and diesel that were used. Once again, $\mathrm{S} 1_{\text {soil conditioner }}$ performed the best and had the highest $\mathrm{CDP}$ among advanced $\mathrm{CFB}$ 
scenarios due to the recycled semi-compost as a soil conditioner substituting phosphate fertilizer and other useful resources, as well as a high recovery of electricity.
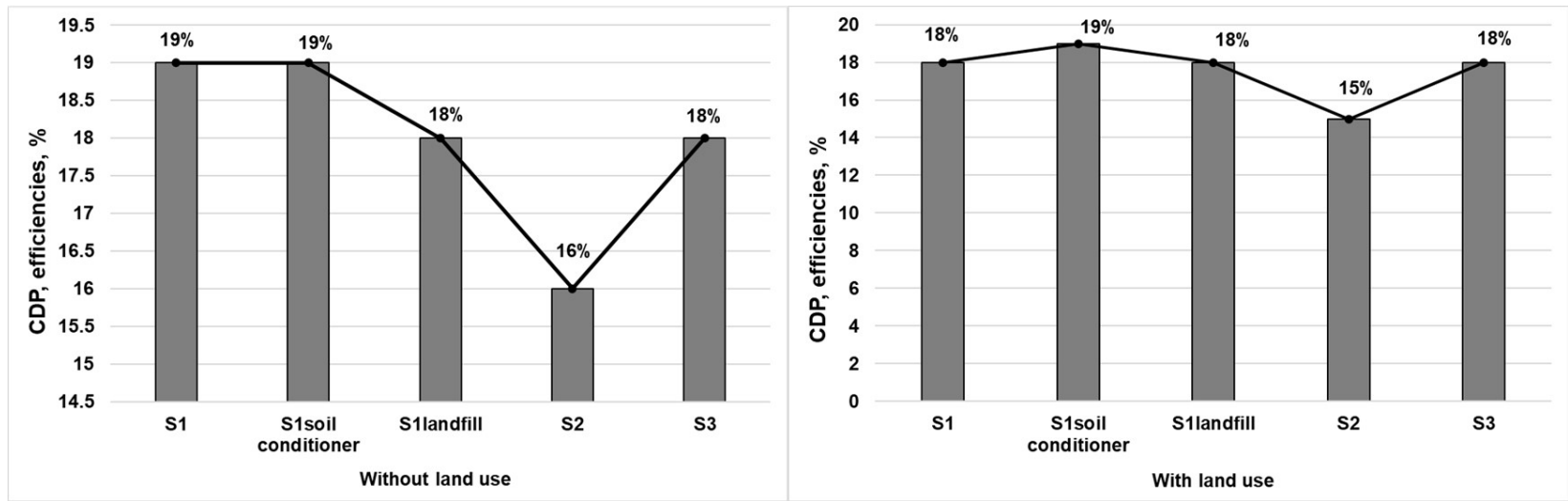

Figure 7. Cumulative degree of perfection (CDP) of the selected systems.

\section{Conclusions}

For the sake of applying the life cycle assessment to an advanced circulating fluidized bed incineration system, five scenarios were proposed and parallel comparisons were conducted from the environmental impacts and exergetic efficiency perspectives using the methods of LCA and ELCA.

The results showed that the advanced circulating fluidized bed incineration system (S1) exhibited higher net environmental savings and CExC efficiencies than conventional circulating fluidized beds (S2) and moving grate (S3) incineration systems due to a higher energy and material recovery.

The different energy and material recovery waste treatment scenarios in the process improvements were assessed. The scenario $\left(\mathrm{S} 1_{\text {soil conditioner }}\right)$ using semi-compost as a soil conditioner obtained the highest net environmental savings, CExC efficiency, CDP and AbatCExC efficiency, indicating the positive improvements which could be achieved if semi-compost was used for material recovery rather than energy recovery.

The ELCA was also conducted based on the consideration of land use. It was observed that a more thorough and scientific evaluation could be achieved with the combination of land resources and ECLA.

Supplementary Materials: The following are available online at https://www.mdpi.com/article/ 10.3390/ijerph181910432/s1, Figure S1: The technological process of advanced CFB incineration system, Table S1: Semi-compost Characteristics Employed in S1, S1soil conditioner and S1landfill scenario; Figure S2: The technological process of MG incineration system (S3), Table S2: Limited values for heavy metals in soil conditioner GB/T 23349-200; Figure S3: The figuration of EHE: 1-ash inlet 2-ash back 3-equalizing air chamber 4-high temperature superheater outlet header 5-high temperature superheater inlet header 6-high temperature superheater serpentine tube 7-ash back overflow hole, Table S3: Inventory of each scenario for the treatment of $1 \mathrm{t}-\mathrm{MSW}$; Table S4: Cumulative exergy consumption (CExC) and abatement exergy (AbatEx) of materials/energy flows and air emissions, as well as the net primary production (NPP) of land use; Table S5: The total abatement exergy loss of the considered scenarios and relevant AbatCExC efficiency with or without considering land use.

Author Contributions: Conceptualization, J.L. and L.W.; methodology, J.L.; software, J.L.; validation, J.L. and L.W.; formal analysis, J.L.; investigation, J.L., L.W. and H.Z.; resources, Y.C.; data curation, J.L., L.W. and H.Z.; writing — original draft preparation, J.L.; writing—review and editing, J.L., L.W. and Y.T.; visualization, J.L.; supervision, Y.C., Y.T., Z.Z. and L.W.; project administration, J.L.; funding acquisition, Y.C. All authors have read and agreed to the published version of the manuscript. 
Funding: This research was funded by the National key research and development program grant number 2018YFC1901300.

Institutional Review Board Statement: Not applicable.

Informed Consent Statement: Not applicable.

Data Availability Statement: The data presented in this study for calculation are available in this manuscript and Supplementary Materials. While the raw data are available on request from the corresponding author, and are not publicly available due to enterprise privacy.

Acknowledgments: The authors gratefully acknowledge the financial support from the National key research and development program (Grant Number: 2018YFC1901300), National Natural Science Foundation of China (No. 51676170).

Conflicts of Interest: The authors declare that they have no known competing financial interest or personal relationships that could have appeared to influence the work reported in this paper.

\section{References}

1. Chinese Statistics Yearbook Compiling Committee. 2017. Available online: http://www.stats.gov.cn/tjsj/ndsj/2017/indexeh.htm (accessed on 17 August 2020).

2. Arena, U. Process and technological aspects of municipal solid waste gasification. A review. Waste Manag. 2012, 32, 625-639. [CrossRef] [PubMed]

3. Liu, Y.; Ni, Z.; Kong, X.; Liu, J. Greenhouse gas emissions from municipal solid waste with a high organic fraction under different management scenarios. J. Clean. Prod. 2017, 147, 451-457. [CrossRef]

4. Rademakers, P.; Hesseling, W.; Van de Wetering, J. Review on corrosion in waste incinerators, and possible effect of bromine. TNO Ind. Technol. 2002, 18-25. Available online: https:/ / citeseerx.ist.psu.edu/viewdoc/download?doi=10.1.1.475.2831\&rep= rep1\&type $=$ pdf (accessed on 17 August 2020).

5. Zhang, H.; Yu, S.; Shao, L.; He, P. Estimating source strengths of $\mathrm{HCl}$ and $\mathrm{SO}_{2}$ emissions in the flue gas from waste incineration. J. Environ. Sci. 2019, 75, 370-377. [CrossRef] [PubMed]

6. Ng, K.S.; Phan, A.N.; Iacovidou, E.; Ghani, W.A.W.A.K. Techno-economic assessment of a novel integrated system of mechanicalbiological treatment and valorization of residual municipal solid waste into hydrogen: A case study in the UK. J. Clean. Prod. 2021, 298, 126706. [CrossRef]

7. Kosajan, V.; Wen, Z.; Fei, F.; Dinga, C.D.; Wang, Z.; Liu, P. Comprehensive assessment of cement kiln co-processing under MSW sustainable management requirements. Conserv. Recycl. 2021, 2021, 174. [CrossRef]

8. Trulli, E.; Ferronato, N.; Torretta, V.; Piscitelli, M.; Masi, S.; Mancini, I. Sustainable mechanical biological treatment of solid waste in urbanized areas with low recycling rates. Waste Manag. 2018, 71, 556-564. [CrossRef] [PubMed]

9. Ma, C.Y. Analysis of Characters in Start-up and Operation of External Heat Exchanger for Circulating Fluidized Bed MSW Incinerator. Therm. Power Gener. 2010, 39, 46-48.

10. Cai, R.; Deng, B.; Tao, X.; Zhang, Y.; Yang, H.; Yue, G.; Zhang, M. Effects of horizontal tube arrays on heat transfer in an external heat exchanger. Appl. Therm. Eng. 2020, 181, 115964. [CrossRef]

11. Li, D.; Cai, R.; Zhang, M.; Yang, H.; Choi, K.; Ahn, S.; Jeon, C.-H. Operation characteristics of a bubbling fluidized bed heat exchanger with internal solid circulation for a 550-MWe ultra-supercritical CFB boiler. Energy 2020, 192, 116503. [CrossRef]

12. Rebitzer, G.; Ekvall, T.; Frischknecht, R.; Hunkeler, D.; Norris, G.; Rydberg, T.; Schmidt, W.P.; Suh, S.; Weidema, B.P.; Pennington, D.W. Life cycle assessment Part 1: Framework, goal and scope definition, inventory analysis, and applications. In Environment International; Elsevier Ltd.: Amsterdam, The Netherlands, 2004; Volume 30, pp. 701-720. [CrossRef]

13. Astrup, T.F.; Tonini, D.; Turconi, R.; Boldrin, A. Life cycle assessment of thermal Waste-to-Energy technologies: Review and recommendations. Waste Manag. 2015, 37, 104-115. [CrossRef]

14. Bakas, I.; Clavreul, J.; Saraiva, A.B.; Niero, M.; Hauschild, M.Z.; Laurent, A.; Gentil, E. LCA of Solid Waste Management Systems. In Life Cycle Assessment; Hauschild, M., Rosenbaum, R., Olsen, S., Eds.; Springer: Cham, Switzerland, 2018. [CrossRef]

15. Singh, A.; Olsen, S.I.; Pant, D. Importance of Life Cycle Assessment of Renewable Energy Sources. In Life Cycle Assessment of Renewable Energy Sources. Green Energy and Technology; Singh, A., Pant, D., Olsen, S., Eds.; Springer: London, UK, 2013. [CrossRef]

16. Dong, J.; Jeswani, H.K.; Nzihou, A.; Azapagic, A. The environmental cost of recovering energy from municipal solid waste. Appl. Energy 2020, 267, 114792. [CrossRef]

17. Hong, J.; Chen, Y.; Wang, M.; Ye, L.; Qi, C.; Yuan, H.; Zheng, T.; Li, X. Intensification of municipal solid waste disposal in China. Renew. Sustain. Energy Rev. 2017, 69, 168-176. [CrossRef]

18. Galli, F.; Pirola, C.; Previtali, D.; Manenti, F.; Bianchi, C.L. Eco design LCA of an innovative lab scale plant for the production of oxygen-enriched air. Comparison between economic and environmental assessment. J. Clean. Prod. 2018, 171, 147-152. [CrossRef]

19. Dong, J.; Chi, Y.; Tang, Y.; Wang, F.; Huang, Q. Combined Life Cycle Environmental and Exergetic Assessment of Four Typical Sewage Sludge Treatment Techniques in China. Energy Fuels 2014, 28, 2114-2122. [CrossRef] 
20. Zhou, Z.; Chi, Y.; Dong, J.; Tang, Y.; Ni, M. Model development of sustainability assessment from a life cycle perspective: A case study on waste management systems in China. J. Clean. Prod. 2019, 210, 1005-1014. [CrossRef]

21. Tang, Y.; Dong, J.; Li, G.; Zheng, Y.; Chi, Y.; Nzihou, A.; Weiss-Hortala, E.; Ye, C. Environmental and exergetic life cycle assessment of incineration- and gasification-based waste to energy systems in China. Energy 2020, 205, 118002. [CrossRef]

22. Wang, Y.; Zhang, J.; Zhao, Y.; Li, Z.; Zheng, C. Exergy life cycle assessment model of " $\mathrm{CO}_{2}$ zero-emission" energy system and application. Sci. China Technol. Sci. 2011, 54, 3296-3303. [CrossRef]

23. Morosuk, T.; Tsatsaronis, G.; Koroneos, C. Environmental impact reduction using exergy-based methods. J. Clean. Prod. 2016, 118, 118-123. [CrossRef]

24. Wang, S.; Liu, C.; Liu, L.; Xu, X.; Zhang, C. Ecological cumulative exergy consumption analysis of organic Rankine cycle for waste heat power generation. J. Clean. Prod. 2019, 218, 543-554. [CrossRef]

25. Szargut, J.; Morris, D.R.; Steward, F.R. Cumulative exergy consumption and cumulative degree of perfection of chemical processes. Int. J. Energy Res. 1987, 11, 245-261. [CrossRef]

26. Bösch, M.E.; Hellweg, S.; Huijbregts, M.A.; Frischknecht, R. Applying cumulative exergy demand (CExD) indicators to the ecoinvent database. Int. J. Life Cycle Assess. 2007, 12, 181. [CrossRef]

27. Dong, J.; Chi, Y.; Zou, D.; Fu, C.; Huang, Q.; Ni, M. Energy-environment-economy assessment of waste management systems from a life cycle perspective: Model development and case study. Appl. Energy 2014, 114, 400-408. [CrossRef]

28. Erb, K.H.; Krausmann, F.; Gaube, V.; Gingrich, S.; Bondeau, A.; Fischer-Kowalski, M.; Haberl, H. Analyzing the global human appropriation of net primary production-Processes, trajectories, implications. An introduction. In Ecological Economics; Elsevier: Amsterdam, The Netherlands, 2009; Volume 69, pp. 250-259. [CrossRef]

29. Haberl, H.; Erb, K.H.; Krausmann, F.; Gaube, V.; Bondeau, A.; Plutzar, C.; Gingrich, S.; Lucht, W.; Fischer-Kowalski, M.; Designed, F.-K.; et al. Sciences of the USA. Proc. Natl. Acad. Sci. USA 2007, 104, 12942-12947. [CrossRef]

30. Bessou, C.; Ferchaud, F.; Gabrielle, B.; Mary, B. Biofuels, Greenhouse Gases and Climate Change. In Sustainable Agriculture; Lichtfouse, E., Hamelin, M., Navarrete, M., Debaeke, P., Eds.; Springer: Dordrecht, The Netherlands, 2011; Volume 2. [CrossRef]

31. Easterling, W.; Apps, M. Assessing the Consequences of Climate Change for Food and forest Resources: A View from the IPCC. Clim. Chang. 2005, 70, 165-189. [CrossRef]

32. Khandelwal, H.; Dhar, H.; Thalla, A.K.; Kumar, S. Application of life cycle assessment in municipal solid waste management: A worldwide critical review. In Journal of Cleaner Production; Elsevier Ltd.: Amsterdam, The Netherlands, 2019; Volume 209, pp. 630-654. [CrossRef]

33. Dewulf, J.; Van Langenhove, H.; Dirckx, J. Exergy analysis in the assessment of the sustainability of waste gas treatment systems. Sci. Total Environ. 2001, 273, 41-52. [CrossRef]

34. Bejan, A. Exergy analysis of thermal, chemical and metallurgical processes. Int. J. Heat Fluid Flow 1989, 10, 87-88. [CrossRef]

35. Alvarenga, R.A.; Dewulf, J.; Van Langenhove, H.; Huijbregts, M.A. Exergy-based accounting for land as a natural resource in life cycle assessment. Int. J. Life Cycle Assess. 2013, 18, 939-947. [CrossRef]

36. Thermodynamics and Sustainable Development: The Use of Exergy Analysis and the Reduction of Irreversibility. Available online: https: / / core.ac.uk/display/11456146 (accessed on 3 October 2021).

37. Dewulf, J.; Van Langenhove, H.; Mulder, J.; Van Den Berg, M.M.D.; Van Der Kooi, H.J.; De, J.; Arons, S. Illustrations towards quantifying the sustainability of technology. Green Chem. 2000, 2, 108-114. [CrossRef]

38. Stougie, L.; Tsalidis, G.A.; van der Kooi, H.J.; Korevaar, G. Environmental and exergetic sustainability assessment of power generation from biomass. Renew. Energy 2018, 128, 520-528. [CrossRef]

39. Zhou, H.; Meng, A.; Long, Y.; Li, Q.; Zhang, Y. An overview of characteristics of municipal solid waste fuel in China: Physical, chemical composition and heating value. In Renewable and Sustainable Energy Reviews; Elsevier Ltd.: Amsterdam, The Netherlands, 2014; Volume 36, pp. 107-122. [CrossRef]

40. Farrell, M.; Jones, D.L. Critical evaluation of municipal solid waste composting and potential compost markets. In Bioresource Technology; Elsevier: Amsterdam, The Netherlands, 2009; Volume 100, pp. 4301-4310. [CrossRef]

41. Lu, J.W.; Zhang, S.; Hai, J.; Lei, M. Status and perspectives of municipal solid waste incineration in China: A comparison with developed regions. In Waste Management; Elsevier Ltd.: Amsterdam, The Netherlands, 2017; Volume 69, pp. 170-186. [CrossRef]

42. Prins, M.J.; Ptasinski, K.J.; Janssen, F.J.J.G. Thermodynamics of gas-char reactions: First and second law analysis. Chem. Eng. Sci. 2003, 58, 1003-1011. [CrossRef]

43. Arena, U.; Ardolino, F.; Di Gregorio, F. A life cycle assessment of environmental performances of two combustion- and gasificationbased waste-to-energy technologies. Waste Manag. 2015, 41, 60-74. [CrossRef]

44. Banar, M.; Cokaygil, Z.; Ozkan, A. Life cycle assessment of solid waste management options for Eskisehir, Turkey. Waste Manag. 2009, 29, 54-62. [CrossRef] [PubMed]

45. Beigl, P.; Salhofer, S. Comparison of ecological effects and costs of communal waste management systems. Resour. Conserv. Recycl. 2004, 41, 83-102. [CrossRef]

46. Buttol, P.; Masoni, P.; Bonoli, A.; Goldoni, S.; Belladonna, V.; Cavazzuti, C. LCA of integrated MSW management systems: Case study of the Bologna District. Waste Manag. 2007, 27, 1059-1070. [CrossRef]

47. Güereca, L.P.; Gassó, S.; Baldasano, J.M.; Jiménez-Guerrero, P. Life cycle assessment of two biowaste management systems for Barcelona, Spain. Resour. Conserv. Recycl. 2006, 49, 32-48. [CrossRef] 